Greek myth' (84). Hermagorean rhetoric, which was primarily concerned with finding effective arguments to deploy in forensic and deliberative debate, had little or nothing to do with pre-existing, traditional myth. Where does that leave us? Lively provides us with (metaphorically) a map of some dense narratological terrain(s) and (literally) a useful bibliography. The map is overloaded and lacks precision in detail; and sometimes, as in the misconception of rhetoric, it is likely to lead us astray. Yet this is, without doubt, a book worth reading. I am sure that I will return to it repeatedly as an aid to thinking about the issues it raises.

MALCOLM HEATH

University of Leeds, UK m.f.heath@leeds.ac.uk doi:10.1017/S0017383520000285

\title{
Latin Literature
}

These days Flavian epic and intertextuality go together like toast and butter, or a persistent cough and fever, depending on your taste. Either way, Intertextuality in Flavian Epic. Contemporary Approaches is not perhaps the most startling of titles. But the book within is an impressive collection, its four editors (Neil Coffee, Chris Forstall, Lavinia Galli Milić, and Damien Nelis) leading a star cast of Flavians in a wide-ranging and stimulating set of chapters. ${ }^{1}$

There's no particular angle ('Flavian poets and prose/Greek epic/politics etc.'), except that digital humanities get a special place. Twenty chapters give good hearing to all four epics; the Silvae also get smuggled past the title, by Carole Newlands. Topics and approaches range nicely, including for instance 'The Flavian Epics and the Neoterics' (Mark Dewar), the politics of epic theology (Thomas Baier), and 'Todeskette in Flavian Epic' (Antony Augoustakis; striking that no one at De Gruyter caught the slip); there's not a single instance of the 'spin out a single lexical parallel for fifteen pages' technique. Federica Bessone is a particularly stimulating read on 'allusive (im-)pertinence' in Statius, with a rich blend of unapologetic formalism and smart interpretation. Another highlight is Damien Nelis on Argonautica 5, showing just how minutely Flaccus responds to Virgil's imitation of Apollonius: it's a neat sequel to Nelis' own landmark study of that imitation, ${ }^{2}$ and a taste, we are promised (83), of a fuller investigation to come.

The digital theme is processed in a group of chapters by Neil Bernstein, Peter Heslin (creator of the Diogenes software), Neil Coffee (who runs the Tesserae website) with his student James Gawley, and Stephen Hinds. There is some banality along the lines of 'computers make it easy to spot lexical matches, but that still leaves

${ }^{1}$ Intertextuality in Flavian Epic Poetry. Contemporary Approaches. Edited by Neil Coffee, Chris Forstall, Lavinia Galli Milić, and Damien Nelis. Trends in Classics, Supplementary Volume 64. Berlin, De Gruyter, 2020. Pp. ix + 476. Hardback £100, ISBN: 978-3-11-059768-4.

${ }^{2}$ D. Nelis, Vergil's Aeneid and the Argonautica of Apollonius Rhodius (Leeds, 2001).

(C) The Author(s), 2021. Published by Cambridge University Press on behalf of The Classical Association. This is an Open Access article, distributed under the terms of the Creative Commons Attribution licence (http://creativecommons.org/licenses/by/4.0/), which permits unrestricted re-use, distribution, and reproduction in any medium, provided the original work is properly cited. 
interpretative work to be done by humans', but happily rather more too: Bernstein tries 'algorithmic criticism', i.e. digitally encoding how intensively authors imitate each other (with limited success so far); Heslin writes technically about how word-search tools are built; Coffee and Gawley test how far intertextuality rests on rare diction (they find that it frequently does, but they would find that, given that their datasets take scant account of e.g. ideas or narrative structure). Finally, Stephen Hinds writes about the 'Pre- and Post-Digital Poetics of "Transliteralism"; he exercises the grandee's right to revisit old material and to ignore the brief, more or less (Flavian epic surfaces only rarely), but raises characteristically interesting questions about the challenge of studying Greek/ Roman intertextuality with computers.

If intertextuality isn't your thing, Robert Simms's Anticipation and Anachrony in Statius' Thebaid is something completely different. ${ }^{3}$ How, he asks, does Statius 'create a compelling story' (cover) when we already know how the Theban saga goes? To this simply put question comes a simple enough answer, in the form of a selective readthrough of the poem; narratology is lightly invoked, but the method is essentially to consider the putative effect on a first-time reader. Confidence is not inspired by the opening pages ('bellum gerare', 'Aeschylus' Sephem', etc., etc.): evidently Bloomsbury is sticking by its policy of letting authors embarrass themselves unfettered.

You could be forgiven a little wariness, then, in approaching Lucan's Imperial World, an edited volume in the same series. ${ }^{4}$ Happily, such suspicions prove unwarranted, despite the talk of Lucan as 'a principle successor' to Virgil and Ovid (1). Editors Laura Zientek and Mark Thorne present a tidy dozen chapters on Lucan and his poem 'as products of their own time' (2) - not perhaps as neglected a theme as they would have it, but a respectable one for all that. Topics include intertextuality with Seneca (Paul Roche, in a strong opener) and Persius, Lucan's Cato and his views on mining - two separate chapters, I hasten to add - compared with Seneca's, Apollo, the Syrtes, and Parthia. E. V. Mulhern on 'Lucan's Nostalgia and the Infection of Memory' identifies a nostalgia for a republican past which the poem both evinces and rejects, in a stimulating chapter, while Andrew McClellan's 'Lucan's Neronian res publica restituta' sets out, with suitable bleakness, to exhume a Lucanian 'necropolitics' (aristocracy under autocracy as 'the living dead').

Ovid gets an edited volume too, Metamorphic Readings. ${ }^{5}$ Sections address in turn (brace yourself) 'Transformations' into, in, and of the Metamorphoses, which is to say, (i) Ovid and his Greek predecessors (a single chapter, by Alessandro Barchiesi); (ii) five readings, three by episode (Deucalion and Pyrrha, Arethusa, Byblis), one on gender, and one identifying a telestich NASO as Cupid fires his arrow in Met. 1.422-5 (Mathias Hanses); and (iii) four chapters on reception, including Philip Hardie on Prudentius, Dante, and Milton.

\footnotetext{
${ }^{3}$ Anticipation and Anachrony in Statius' Thebaid. By Robert Simms. London, Bloomsbury Academic, 2020. Pp. vii + 208. Hardback £85, ISBN: 978-1-3500-8257-1.

${ }^{4}$ Lucan's Imperial World. The Bellum Civile in Its Contemporary Context. Edited by Laura Zientek and Mark Thorne. London, Bloomsbury Academic, 2020. Pp. xii $+256.5 \mathrm{~b} / \mathrm{w}$ illustrations. Hardback £85, ISBN: 978-1-3500-9741-4.

${ }^{5}$ Metamorphic Readings. Transformation, Language, and Gender in the Interpretation of Ovid's Metamorphoses. Edited by Alison Sharrock, Daniel Möller, and Mats Malm. Oxford, Oxford University Press, 2020. Pp. xii + 254. Hardback £65, ISBN: 978-0-19-886406-6.
} 
Alison Keith's student introduction to Virgil treads a familiar path through 'life and times', the three works (each read sequentially), and reception; the didaxis is finely judged, with plenty of material digested into eminently readable prose, tidily pared endnotes, and a bibliography which ventures beyond English. ${ }^{6}$ Much attention is given to Virgil's Epicureanism and Lucretian intertextuality, a welcome surprise (no hint of that on the cover). The other thing that struck me most is the lack of 'problematizing'. The invocation of Erato in Aeneid 7.37, for instance, becomes strangely unremarkable: 'Erato is the muse who presides over erotic themes in classical literature and so Virgil appropriately invokes her at the start of his Iliadic books' (109, my emphasis). And long-running ideological battles are swept away en masse: readers of this book will not so much as hear of 'optimists' and 'pessimists', of 'Harvard' and 'European' schools - a merciful release for some, no doubt, but also a missed opportunity to give some important critical orientation. It's a nice touch that Keith, author of a fine book on gender in Latin epic, ${ }^{7}$ seems almost to have forgotten about that subject - until her parting shot: where the Aeneid begins with arms and a man, she ends with Ursula Le Guin's 'gynocentric' (150) rewrite in her novel Lavinia (2008).

Back to the Flavians, and Valerius Flaccus is edging closer to a full house of singlebook commentaries in English with P. J. Davis' Argonautica $7 .^{8}$ It launches a new series of 'Oxford Commentaries on Flavian Poetry', presided over by seven sages, a.k.a. 'General Editors' (whether they exert any control beyond commissioning, we are not told). The material - one of Medea's great erotic turns in Latin - makes Book 7 an attractive way into the poem, and Davis writes inclusively, adopting an easy-going, expansive style as he ranges from nuts and bolts to textual criticism (his text is partly based on autopsy) by way of literary criticism and, naturally, much intertextuality; scholarly citation is abundant. The Introduction touches only briefly on date (following the Vespasianic communis opinio), politics, and style, and you'll have to look elsewhere for a summary of the whole poem; instead, a pair of essays treat the Medea myth before and in Valerius, and a third offers three 'snapshots' of reception - starting, nicely enough, with the Achilleid.

Peter Habermehl on Petronius takes 'expansive' to a different level, with 400 pages devoted to Satyrica 111-18. ${ }^{9}$ The second half of the novel has got busier since Habermehl started his project of commenting on it, ${ }^{10}$ but that has not stopped him expanding it from a major project (two volumes) to a monumental one (four). Ample space here, then, for minute and learned scrutiny of the Widow of Ephesus,

${ }^{6}$ Virgil. By Alison Keith. Understanding Classics. London, Bloomsbury Academic, 2020. Pp. ix +208 . Hardback £50, ISBN: 978-1-8488-5919-7; paperback £16.99, ISBN: 978-1-8488-5920-3.

${ }^{7}$ A. M. Keith, Engendering Rome. Women in Latin Epic (Cambridge, 2000).

${ }^{8}$ Valerius Flaccus. Argonautica, Book 7. Edited with Introduction, Translation, and Commentary by P. J. Davis. Oxford Commentaries on Flavian Poetry. Oxford, Oxford University Press, 2020. Pp. xii + 299. Hardback £85, ISBN: 978-0-19-876719-0.

${ }^{9}$ Petronius, Satyrica 79-141. Ein philologisch-literarischer Kommentar. Band 2. Sat. 111-118. By Peter Habermehl. Texte und Kommentare 27/2. Berlin, De Gruyter, 2020. Pp. lxxix +320 . Hardback £100, ISBN: 978-3-11-019109-7.

${ }^{10}$ P. Habermehl, Petronius, Satyrica 79-141. Ein philologisch-literarischer Kommentar. Band 1. Sat. 79-110 (Berlin, 2006), was followed by G. Vannini on Sat. 110-15 (Berlin, 2010) and G. Schmeling with A. Setaioli on the whole novel (Oxford, 2011). 
along with the storm and arrival at Croton; we end with Eumolpus poised to declaim his Civil War - but for Habermehl's views on that we have to wait a year or two more.

Stefano Rocchi's commented edition of Vergilius orator an poeta looks slim by comparison, but looks can deceive: after all, he has less than three pages of Latin text to deal with. ${ }^{11}$ This is the first commentary on Florus' dialogue, or rather the slender remains of it: we never do find out whether Virgil was an orator or a poet; but we have the start of the preface, an interesting mise en scène in the world of a provincial man of letters under Trajan. Rocchi's Introduction gives circumspect treatment to questions of authorship (he inclines to 'P. Annius Florus', and to identifying him with the Florus of the Epitome, but has judicious remarks on the stylized autobiography presented in the Virgil), dramatic date (explicitly Trajanic), and date of composition (staked as Hadrianic); more speculatively, he wonders if Hadrian's stay at Tarraco in 122/3 prompted Florus to write a dialogue for the literarily minded emperor. Prose style, rhythm, and intertextuality get several pages, as do the traces - if they are that - of later antique reception; then come a critical text with Italian translation, and a substantial, essayistic commentary.

The first volume of Stephen Oakley's Studies in the Transmission of Latin Texts (at least two more are promised) is devoted to Curtius Rufus' history of Alexander the Great and the pseudo-eyewitness account of the Trojan War written by 'Dictys of Crete' and translated into Latin in the third or fourth century. ${ }^{12}$ Oakley is best known for his four-volume commentary on Livy 6-10 (Oxford, 1997-2005); this next endeavour, if more specialist, is set to be equally monumental. Extant manuscripts are catalogued and sorted stemmatically; the conclusions on both Curtius and 'Dictys' confirm existing views of their traditions in broad outline, but refine those views in several ways. Oakley's 'ideal readers' are a select crowd, namely future editors of the two texts; but the vast and minute erudition accumulated on these pages will keep all students of textual transmission well occupied.

Today's winner for bulk, though, is Sidonius Apollinaris, subject of a hefty Edinburgh Companion edited by Gavin Kelly and Joop van Waarden. ${ }^{13}$ Twenty-four chapters situate Sidonius in his historical and social context (late fifth-century Gaul), examine the language and literary texture of his diverse works (panegyrics, poetry, epistles), and survey the textual tradition and reception. If that range of topics is not unexpected, what makes this companion remarkable is its depth and originality: the editors' learned chapter on prose rhythm, for instance, Franz Dolveck's conspectus of the extant manuscripts, or Sigrid Mratschek's re-evaluation of Sidonius' epistolary aesthetics. The dustjacket promises a book which 'will set the stage for a generation or more of research on Sidonius': that's no exaggeration.

${ }^{11}$ P. Annio Floro, 'Virgilio. Oratore o poeta?' Introduzione, testo critico, traduzione e commento. By Stefano Rocchi. Texte und Kommentare 65. Berlin, De Gruyter, 2020. Pp. xi + 183. Hardback £100, ISBN: 978-3-11-068976-1.

${ }_{12}$ Studies in the Transmission of Latin Texts. Volume I. Quintus Curtius Rufus and Dictys Cretensis. By S. P. Oakley. Oxford, Oxford University Press, 2020. Pp. xxvii +505. 5 b/w illustrations. Hardback $£ 100$, ISBN: 978-0-19-884872-1.

${ }^{13}$ The Edinburgh Companion to Sidonius Apollinaris. Edited by Gavin Kelly and Joop van Waarden. Edinburgh, Edinburgh University Press, 2020. Pp. xviii +838. 1 map. Hardback £195, ISBN: 978-1-4744-6169-6. 
Back now, by way of an elegant Tusculum (facing Latin and German) of Claudian's political poems, ${ }^{14}$ to Trajanic Rome and to Sidonius' professed model as elite man of letters, Pliny the Younger. There is a long tradition of Lives of Pliny, as you might expect given all the autobiographical material in his letters, including a major article by Mommsen and more recently a cheerful slim volume by Rex Winsbury. ${ }^{15}$ Roy Gibson's Man of High Empire can fairly claim, though, to be 'the first full-scale biography' (cover) ${ }^{16}$ If the presentation - smooth main text, abundant detail tucked away in endnotes - has a touch of 'Routledge imperial biography' about it, three things make the product distinct. First, the chapters are arranged not just by loose chronology but also geographically (Comum, Campania, Rome, the villas, Pontus-Bithynia): Gibson takes pains to situate Pliny in the spatial nodes of his life, and evidently took time - witness the photos - to explore them for himself. Second, he reflects explicitly and repeatedly on his biographical project, and makes Augustine a surprising and interesting comparandum, pitting Epistles against Confessions. Third, this is a major literary study of the Epistles in its own right (the Panegyricus is largely left aside), immersed in the Latin text and its scholarship, and as alive to nuance as you would expect. The marriage of philology with social history is peculiarly apt to its subject, and would surely have pleased Pliny.

A contrasting pair of novelties while we're on the High Empire. How to Be a Bad Emperor is a literally pocket-sized guide to four of Suetonius' Caesars (Julius, Tiberius, Caligula, Nero): brief extracts in Latin with English by Josiah Osgood, plus snappy introduction and a few endnotes. ${ }^{17}$ It's printed on petite pages with wide spacing, as part of a series called 'Ancient Wisdom for Modern Readers' - and it doesn't take long to see where the lesson in this tale of 'truly terrible leaders' lies: 'As president in the White House, a man becomes himself, squared...' (vii). ${ }^{18}$

At the less popular end of the market, meanwhile, we find a new Oxford Classical Text of Aulus Gellius. ${ }^{19}$ The Attic Nights is a work of diverse erudition and a fiddly text: hard to imagine a better-qualified editor than Leofranc Holford-Strevens, a

${ }^{14}$ Claudian. Politische Gedichte. Edited and translated by Philipp Weiß and Claudia Wiener. Sammlung Tusculum. Berlin, De Gruyter, 2020. Pp. 934. Hardback £72.50, ISBN: 978-3-11-060750-5.

${ }^{15}$ T. Mommsen, 'Zur Lebensgeschichte des jüngeren Plinius', Hermes 3 (1869), 31-139. I reviewed R. Winsbury, Pliny the Younger. A Life in Roman Letters (London, 2014) in Gnomon 87 (2015), 554-5.

${ }^{16}$ Man of High Empire. The Life of Pliny the Younger. By Roy K. Gibson. New York, Oxford University Press, 2020. Pp. xviii + 298. 12 b/w illustrations, 3 maps. Hardback £19.99, ISBN: 978-0-19-994819-2. I had the fortune to read in it draft too.

${ }_{17}$ Suetonius. How to Be a Bad Emperor. An Ancient Guide to Truly Terrible Leaders. Selected, translated, and introduced by Josiah Osgood. Ancient Wisdom for Modern Readers. Princeton, NJ, Princeton University Press, 2020. Pp. xii +288 . Hardback £13.99, ISBN: 978-0-691-19399-1.

${ }^{18}$ If that remark is no longer topical when you read this (I'm writing the weekend before the 2020 presidential election), I'll have no complaints.

${ }_{19}$ Auli Gelli Noctes Atticae. Praefatio et Libri I-X. Edited by Leofranc Holford-Strevens. Oxford Classical Texts. Oxford, Oxford University Press, 2020. Pp. lxiv + 395. Hardback £50, ISBN: 978-0-19-969501-0. Auli Gelli Noctes Atticae. Libri XI-XX. Edited by Leofranc Holford-Strevens. Oxford Classical Texts. Oxford, Oxford University Press, 2020. Pp. x +368 . Hardback £50, ISBN: 978-0-19-969502-7. 
'details man' par excellence with a taste for what you might call the arcane - when he wants to say 'digitized' in his Latin preface, he produces the archaeoneologism

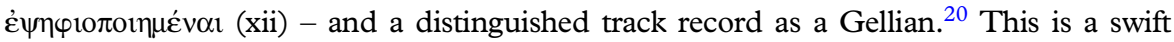
renewal as OCTs go, replacing P. K. Marshall's of 1968, but Holford-Strevens has new manuscript evidence, fine-tunes the stemma, and provides a much fuller critical apparatus, including abundant emendations. A slim companion volume, learned and unforgiving, offers more discursive if still characteristically taut treatment of selected problems, and catalogues corrigenda and addenda to Holford-Strevens' previous Gelliana. ${ }^{21}$

One topic to catch Gellius' attention was the Latin accent. Where should the acute fall in affatim? Is Valeri (vocative) pronounced the same as Valeri (genitive)? Should Hannibalem have a circumflex on the penultimate syllable? ${ }^{22}$ Perhaps such questions keep you awake at night too, or perhaps your ears prick up at talk of a Latin circumflex; if so, Philomen Probert's Latin Grammarians on the Latin Accent is the book for you. ${ }^{23}$ This is not, Probert stresses, a treatise on the Latin accent; rather, she tackles a preliminary question: when Latin authors write about accentuation, should we take them seriously? Modern views have varied: some take the distinction of acute and circumflex, for instance, to show that Latin had a pitch accent; others see it as the mechanical mapping of Greek terminology onto a language in which it was meaningless. In response, Probert takes us on an eye-opening tour through some of the highways (Quintilian, Gellius) and byways (Velius Longus, John Philoponus) of the grammatical tradition, working through this often tricky material patiently, plainly, and with admirable clarity. Primary topics include enclitics (Lauiniáque uenit or Lauiniaque uenit?), proclitics (circum 'around' vs círcum 'circus'?), and that circumflex - explained by Probert as a notional accent 'that highly educated Romans could learn to hear' (242). A primary conclusion is that Latin grammarians do indeed try to map Latin accents onto a Greek analytical framework, as they do grammar and syntax; a central idea is the distinction between 'natural accents' as abstract entities and 'concrete' accents actually

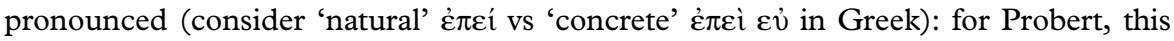
is key to understanding ancient analysis of the Latin accent, and to the tricky business of distinguishing between ancient statements showing how Latin was pronounced and those that reflect only an abstract level of analysis. This won't be everyone's idea of bedtime reading, and it is not, to repeat, a handbook; but you'll never think of néscia Didô in quite the same way again.

Barnaby Taylor's Lucretius and the Language of Nature, another title for the linguistically minded, shares with Probert that eternal topic, the legacy of Greek on Latin. ${ }^{24}$

${ }^{20}$ Notably L. Holford-Strevens, Aulus Gellius. An Antonine Scholar and His Achievements (Oxford, 2003), and L. Holford-Strevens and A. Vardi (eds.), The Worlds of Aulus Gellius (Oxford, 2004).

${ }^{21}$ Gelliana. A Textual Companion to the Noctes Atticae of Aulus Gellius. By Leofranc Holford-Strevens. Oxford, Oxford University Press, 2020. Pp. xx +204 . Hardback £65, ISBN: 978-0-19-969393-1.

${ }^{22}$ NA 6.7.1-5, 4.7, 13.26.1-3.

${ }^{23}$ Latin Grammarians on the Latin Accent. The Transformation of Greek Grammatical Thought. By Philomen Probert. Oxford, Oxford University Press, 2020. Pp. xxvi + 321. Hardback £84, ISBN: 978-0-19-876719-0.

${ }^{24}$ Lucretius and the Language of Nature. By Barnaby Taylor. Oxford Classical Monographs. Oxford, Oxford University Press, 2020. Pp. xi + 223. Hardback £60, ISBN: 978-0-19-875490-9. 
A revised doctoral thesis, it is a literary-linguistic study of Lucretius' 'linguistic innovation and creativity' (cover), with chapters on metaphor, calques, etymology, and Graecisms such as tmesis. The discussion can feel episodic, though that will also make it handy for dipping into, and the Greek background (Plato, Empedocles, Epicurus) gets substantial treatment. Alas for the opening promise to 'characterize

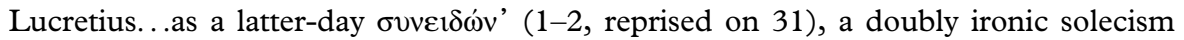

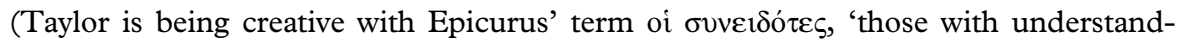
ing'), if happily an outlier.

And so we've reached the Republic at last, only to read it the last rites. Brian Walters' The Deaths of the Republic is a short book/long essay on the imagery of the body politic in the mid-first century вС. ${ }^{25}$ Cicero is inevitably centre-stage throughout, and the apparently thematic arrangement (healing the state, wounding it, killing it) doubles as a chronological one, tracking his career from the 60s. Pro Sestio and Philippics loom largest, but Walters shakes down the whole corpus, with glances too at the scanty remains of other Republican orators and historians.

Robert Kaster's new translation of the Brutus and Orator makes a welcome change from the now dusty Loeb (1939), not just for its modern, easy-going style: Kaster is predictably punctilious on textual matters, and offers a superb introductory essay, including a valiant effort to explain prose rhythm - such a large topic in the Orator - with musical notation and musical parallels (well, kinda) from the likes of Cole Porter. ${ }^{26}$ There are generous notes too, and the De optimo genere oratorum is thrown in as an unadvertised bonus.

The Catilinarians get their first dedicated monograph in a new volume of Oxford Approaches to Classical Literature by Dominic Berry. ${ }^{27}$ Each speech has a chapter, as does the historical context and a reception history running from Virgil to Bill Clinton; the manner is welcoming to novices, but this is also a scholarly study, with new things to say on, for instance, Catiline's canvassing and the position of the fragment o fortunatam natam... ('O blessed Rome...') in Cicero's epic De consulatu suo. Berry emphasizes the merit of reading the four speeches both as quasi-transcripts from 63 BC ('Approach A') and as publications crafted later ('Approach B') - specifically in $60 \mathrm{BC}$, and comprising, he estimates, about ten per cent addition and ninety per cent revision. I doubt mine will be the only eye caught by his comparison of the product with Piers Morgan's Private Diaries (83-7; how would Cicero have felt about that?).

William Batstone and Andrew Feldherr have teamed up for an Oxford Readings in Classical Studies volume on Sallust. ${ }^{28}$ Books in this series offer 'a representative

${ }^{25}$ The Deaths of the Republic. Imagery of the Body Politic in Ciceronian Rome. By Brian Walters. Oxford, Oxford University Press, 2020. Pp. xvi + 158. 3 b/w illustrations. Hardback £60, ISBN: 978-0-19-8883957-6.

${ }^{26}$ Cicero. Brutus and Orator. Translated, with Introduction and Notes, by Robert A. Kaster. Oxford, Oxford University Press, 2020. Pp. xi +311 . Hardback £64, ISBN: 978-0-19-085784-4; paperback £16.99, ISBN: 978-0-19-085785-1.

${ }^{27}$ Cicero's Catilinarians. By D. H. Berry. Oxford Approaches to Classical Literature. Oxford, Oxford University Press, 2020. Pp. xviii +276. 9 b/w illustrations, 2 maps. Hardback £64, ISBN: 978-0-19-532646-8; paperback £16.99, ISBN: 978-0-19-532647-5.

${ }^{28}$ Sallust. Edited by William W. Batstone and Andrew Feldherr. Oxford Readings in Classical Studies. Oxford, Oxford University Press, 2020. Pp. xii +494. Hardback £100, ISBN: 978-0-19-879098-3. 
selection of the best and most influential articles' on their subject, which leaves open a cynical question: why pay $£ 100$ for scholarship that is already published elsewhere, and often available online? True, it's handy to be able to send students to a one-stop shop; but I think we're entitled to hope for added value in the introduction (conventionally a 'state of the field' survey), in revisions to the chapters, and in material which is unexpected, harder to get hold of, and/or translated. This one scores well on all points.

The Introduction starts out as something of an interpretative essay, apparently by Batstone, then settles into an account, part-thematic, part-chronological, of scholarship over the last century or so. Then come fifteen chapters: three general, four each on the Bella Catilinae and fugurthae, three on the Histories, and one on reception (Patricia Osmond's richly shaded study of Sallust in the Renaissance, 1995). They include such modern classics as Christina Kraus's 'Jugurthine Disorder' (1999), David Levene's brilliant 'Sallust's Catiline and Cato the Censor' (2000), and Erik Gunderson's 'literary/philosophical' reading (168) of the Catiline (2000); several contributors have taken the trouble to update their pieces, notably Levene, who gives interesting retrospectives both on the Cato piece and on 'Sallust's fugurtha: An "Historical Fragment"' (1992, his debut article). But the volume also looks further back than most, all the way to Eduard Schwartz's 'Die Berichte über die catilinarische Verschwörung' (1897), which reads well even in its quainter moments ('Sallust, who had no other claims to reputation than a thrashing in Milo's boudoir...', 126), and Kurt Latte's Sallust (1935), with its fine-grained account of Sallust's style: positivists rub shoulders with postmodernists, with plenty of shades in between.

Five chapters in all are translated (curious that we're nowhere told explicitly which), including excerpts from Antonio La Penna's Sallustio e la 'rivoluzione' romana (1968). Several are abridged, with varying success: so Friedrich Klingner on the proem to the Histories (1928) has been curiously hollowed out, with half the article - the bit where he quotes and discusses the fragments - excised. Since La Penna (also in the Histories section) keeps his discussion mostly abstract, the reader is left with very little sense of what this least familiar of Sallust's works actually looked and smelled like. Perhaps the editors felt the same problem; certainly it makes Andrew Feldherr's 'The Faces of Discord in Sallust's Histories', new for this volume, all the more welcome, with its scoping of the fragments, its close reading of the opening line, and its argument for 'disunity as a hermeneutic principle for the Histories' (373).

As it happens, the Histories is also the subject of a recent monograph, but I can only report on that at second hand, since no copy has come my way; ${ }^{29}$ I'll slip back instead into the Principate and to one of Sallust's less fortunate successors. In 2016-17 a scroll from the Villa dei Papiri at Herculaneum (P.Herc. 1067) was reidentified as a text of Seneca the Elder's Histories: an exciting find both in terms of Seneca's work (there are no other direct witnesses) and as one of precious few Latin books to survive from the first century AD. Seneca the Elder and His Rediscovered 'Historiae ab initio bellorum civilium' is a conference volume occasioned by that discovery. ${ }^{30}$ The text itself is tucked

\footnotetext{
${ }^{29}$ J. Gerrish, Sallust's Histories and Triumviral Historiography. Confronting the End of History (London, 2019).

${ }^{30}$ Seneca the Elder and His Rediscovered 'Historiae ab initio bellorum civilium'. New Perspectives on Early-Imperial Roman Historiography. Edited by Maria Chiara Scappaticcio. Berlin, De Gruyter, 2020. Pp. ix + 425. 7 colour illustrations. Hardback £118, ISBN 978-3-11-068585-5.
} 
away in an appendix (356-68); it is lacunose, to say the least (sample an.eri $[\mid c[o] m m[\mid$ alter[...] $\operatorname{rr}\left[\mid \operatorname{rogab}\left[\mid\right.\right.$ ut.Ha ${ }^{\prime}{ }^{\prime}[e r i-\mid \operatorname{var}[|| \mid$ ]șena[t- | ]ṿeț[·]sẹn. [ from cornice 2, pezzo 1), so no wonder we don't get a translation; but Valeria Piano, who published the editio princeps ${ }^{31}$ gives a useful first tour (now in English) of the contents, along with an account of her detective work. Three more chapters address the papyrus's context and contents; others broaden the gaze, for instance by scouring later authors (Suetonius, Tacitus, Florus) for Senecan influence, or in Stephen Oakley's essay on prose style in contemporary historians (primarily Velleius Paterculus). It's not surprising to find Lewis Sussman (of The Elder Seneca fame ${ }^{32}$ ) contributing; rather more so that his paper - an attempt to reconstruct the Histories through the Controversiae and Suasoriae - dates from 1972; but I suppose this was as good a place as any for it to see daylight at last.

Two gods to finish. Dionysus and Rome is an impressive collection edited by Fiachra Mac Góráin. ${ }^{33}$ The subtitle, 'Religion and Literature', strikes an ambitious note with its invocation of Dennis Feeney, ${ }^{34}$ and the eight chapters take a suitably varied range of approaches - mainly literary, but there's history and archaeology too - to Dionysus/ Bacchus/Liber in Rome. So, for instance, Gesine Manuwald catalogues Cicero's occasional references to him, John F. Miller reads Tristia 5.3 on the Liberalia, and Francesco Massa surveys Christian takes from Tertullian to Firmicus Maternus. Alessandro Schiesaro on Bacchus in the Thebaid is a highlight, rich in detail and interpretative ambition; another is Mac Góráin's Introduction, which goes well beyond the norm in range, depth, and quality to make an important essay in its own right: appetites are whetted for his forthcoming monograph, Virgil's Dionysus.

But let us end, as Aratus didn't say, with Jupiter. Julia Dyson Hejduk studies 'The God of Rome' in Virgil, Horace, Tibullus, Propertius, and Ovid in his manifold guises as father, thunderer, philanderer/rapist, and of course celestial monarch. ${ }^{35}$ The mode is appealing, the discussion varied, nuanced, and not without surprises - including on that most slippery of equations, Augustus $=$ ? Jupiter. At faueam lingua...

CHRISTOPHER WHITTON University of Cambridge, UK

clw36@cam.ac.uk doi:10.1017/S0017383520000297

\footnotetext{
${ }^{31}$ V. Piano, 'Il PHerc. 1067 latino: il rotolo, il testo, l'autore', CErc 47 (2017), 163-250, available at <http://www.fedoa.unina.it/11211/1/Piano_CronacheErcolanesi\%2047_2017.pdf>, accessed 31 October 2020.

${ }^{32}$ L. A. Sussman, The Elder Seneca (Leiden, 1978).

${ }_{3}$ Dionysus and Rome. Religion and Literature. Edited by Fiachra Mac Góráin. Trends in Classics, Supplementary Volume 93. Berlin, De Gruyter, 2020. Pp. xii +247 . 11 colour illustrations, 1 table. Hardback $f 91$, ISBN: 978-3-11-067156-8. My apologies to Fiachra for the typo in his name in GESR 67.1 (2020), 80.

${ }^{34}$ D. Feeney, Literature and Religion at Rome. Cultures, Contexts, and Beliefs (Cambridge, 1992).

35 The God of Rome. Fupiter in Augustan Poetry. By Julia Dyson Hejduk. Oxford, Oxford University Press, 2020. Pp. xii + 340. Hardback £47.99, ISBN: 978-0-19-060773-9.
} 